\title{
Journalistica temanummer: Kritiske perspektiver på \#MeToo i Norden: Journalistikken, debatten, bevægelsen
}

TINA ASKANIUS

Malmø Universitet

JANNIE MøLLER HARTLEY

Roskilde Universitet

\section{Introduktion}

Bedst som forfatterne af dette temanummer gjorde klar til at sætte det sidste punktum, skete der i oktober 2020 noget, som få havde set komme. DR-profilen Sofie Lindes personlige vidnesbyrd om seksuelle krænkelser og en 'rådden kultur' i den danske mediebranche på Zulu Comedy Awards-scenen kickstartede en omfattende debat, underskriftsindsamlinger og vidneberetninger i hobetal. Tre år efter, at \#metoo-bølgen for første gang skyllede ind over verden, synes bevægelsen endelig at være kommet til Danmark.

Hendes tale fik i første omgang en blandet modtagelse - nogle mente, at det var et forkert forum at belyse problemet $i$, mens andre støttede hende i at bruge sin position og taletid som vært til at sætte spot på problemet. Umiddelbart efter Lindes tale så vi chefredaktører ty til trusler og påstande om kvindelige journalisters inhabilitet, et massivt krav om at nævne navne og beskyldninger om personlige vendettaer. Man kan sige, at udmeldingen indledningsvist fik samme kølige modtagelse som \#metoo-bevægelsen fik i Danmark i 2017. Man forsøgte at lukke den ned, og man satte spørgsmålstegn ved Lindes troværdighed. 
Men Sofie Linde stod ikke alene, og støtteerklæringerne fik for alvor sat fut i den danske \#metoo med mediebranchen helt $\mathrm{i}$ front. En gruppe kvindelige journalister fra TV2 delte nogle dage efter et åbent brev, hvori de erklærede deres støtte til Sofie Linde og beskrev, hvordan hun ikke var alene med sin oplevelse. Brevet blev efterfølgende delt i specielt mediebranchen, og på få dage havde 1.615 kvinder skrevet under på støtteerklæringen, og det fik for alvor debatten til at rulle. Flere mediechefer begyndte at stå frem og love granskning og forandring i branchen, men de mødte også kritik fra tidligere ansatte. Blandt andet chefredaktør på Ekstra Bladet, Poul Madsen. Tidligere ansatte på Ekstra Bladet stod frem og fortalte om en længerevarende sexchikanesag på avisen, der begyndte i 2008. Først i 2019 blev lederen fyret efter adskillige anonyme vidnesbyrd om 'brutal ledelse' og sexisme. I mellemtiden havde Poul Madsen forfremmet lederen og givet ham en advarsel for sexchikane. Poul Madsen gav sig selv 'mundkurv' på i sagen, selvom det var ham, der i sin tid valgte at forfremme den pågældende person, og på trods af at han kendte til anklagerne om sexchikane. Poul Madsen erkender dog at have 'svigtet sit ansvar', efter at 46 tidligere og nuværende kvindelige ansatte på avisen er stået frem i et åbent brev med beskyldninger om et 'sexistisk miljø' på avisen. På TV2, hvor en del af initiativtagerne til den første undersøgelse arbejdede, blev de kvindelige underskrivere først mødt med et krav om at påkalde sig inhabilitet i dækningen af \#metoo, men efterhånden som kritikken voksede, blev det også her til interne undersøgelser og selvransagelse. DR fik kritik i flere sager, men særligt sagen om chikanerede adfærd fra en DR-vært førte til intern selvransagelse, afskedigelser og nye tiltag for at dæmme op for problemerne med grænseoverskridende adfærd på redaktionerne. Svaret på, hvorfor det tog så lang tid for \#metoo-bevægelsen at komme til Danmark, og hvorfor vi i Danmark stadig har så svært ved at tale om sexisme og ligestilling, skal ikke bare findes i debatkulturen, men også i kulturen i nyhedsrummet rundt omkring i landet.

Kort tid efter blev dansk politik ramt af, hvad der nærmest kun kan betegnes som et \#metoo-jordskælv. Igen startede det med vidnesbyrd fra kvindelige politikere, og efter kun få dage kom også konkrete episoder fra partierne frem i lyset. Det betød farvel til to store fremtrædende skikkelser i dansk politik. Først var det Morten Østergaard fra Radikale Venstre, der måtte træde tilbage ovenpå håndteringen af sagen om en hånd på kollega Lotte Rods lår for ti år siden. Efter- 
følgende var det så Københavns overborgmester, Frank Jensen fra Socialdemokratiet, der måtte gå af, efter at en række kvinder stod frem i Jyllands-Posten og fortalte, hvordan overborgmesteren havde krænket dem. Særligt mandlige stemmer begyndte at blande sig i debatten med opbakning til de kvindelige brevskrivere og de andre vidneudsagn. \#MeToo-debatten spredte sig også til andre brancher, hvor den har varslet et opgør med en sexistisk kultur. Kvindelige ledere som Stine Bosse og tidligere statsminister Helle ThorningSchmidt meldte sig i debatten og sagde, at sexisme findes, og at topledelsen i virksomheder har et ansvar for at løse problemet. Alt fra læger til fagforeninger står i skrivende stund midt i hver deres \#metoo-jordskælv, og nye retningslinjer tager form. Undersøgelser af større omfang sættes i gang, og chefer taler om selvransagelse og det lange, seje arbejde, der venter forude.

Meget er altså sket i og omkring bevægelsen, efter den første gang skyllede ind over verden - ikke mindst i de nordiske lande, hvor det lader til, at vi langt fra er ved slutningen af debatten, aktivismen eller nyhedsstrømmen om \#metoo. Bevægelsen har sat et aftryk på den politiske dagsorden i Norden sidste år. De nordiske ligestillings- og arbejdsmarkedsministre har iværksat forskellige initiativer med politiske indsatser omkring fire områder; ny og opdateret lovgivning, ændringer af arbejdsopgaver, krav til arbejdsgivere samt kortlægning og viden. Hvis vi kigger mod den bredere offentlige debat i medierne og måden, hvorpå bevægelsen er håndteret journalistisk, har den dog udviklet sig i vidt forskellige retninger og hen over forskellige tidslinjer i de nordiske lande.

Som nævnt blev en række \#metoo-historier i 2017 lagt på is, eftersom journalister i Danmark vurderede, at de "ikke holdt i retten", hvad angik kildebrug og navneforbud. Efter 'Linde-sagen' dukkede en del af disse historier og konkrete navne op igen - denne gang eksempelvis i forummet 'Jodel', og vi har set en del kritik af, at nyhedsmedierne bygger historier op om, hvad der skrives anonymt i dette og lignende online fora. Flere kritikere peger nu på, at journalister er på vej ud på en presseetisk glidebande. Det gælder ikke mindst svenske Åsa Linderborg, tidligere kulturredaktør på Aftonbladet, som advarer danske journalister mod at lade "\#metoo-revolutionen løbe løbsk" og opfordrer til "ikke at gentage Sveriges fejltrin" (se eksempelvis Berlingske Tidende den 10. oktober 2020). Hun turnerede i efteråret 2020 rundt 
i Danmark og Norge med interviews og foredrag om 'det svenske pressehavari' med udgangspunkt i sin bog Året med 13 måneder, hvori hun i dagbogsform deler sin oplevelse af at stå i stormens øje af den svenske bevægelse og følelsen af at stå alene med sin kritik af pressens håndtering af navnepubliceringer. Under denne periode blev \#metoo i danske medier pludseligt beskrevet som noget, der kunne koste menneskeliv (DR Nyhederne den 26. oktober 2020) med henvisning til den svenske teaterdirektør Benny Frederiksson, der begik selvmord i kølvandet på anklager om, at han drev en tyrannisk arbejds- og ledelseskultur. Benny Frederiksson-sagen har på mange måder sat sit præg på diskussionen om \#metoo og journalistikkens magt og ansvar i tiden efter 2017.

I Sverige har man da også efter \#metoo haft presseetiske tømmermænd. PO/PON (Pressombudsmannen og pressens opinionsnämnd) fældede i princippet alle de udgivelser, hvor aviser, pressede af sociale medier, publicerede navne på anklagede, men ikke dømte personer. I Benny Fredriksson-sagen var kritikken fra PO/PON skarp, men også TV4-programlederen, Martin Timell, fik medhold i anklagerne om dårlig presseetik. De to institutioner sendte dermed et stærkt signal om, at mange udgivere var gået for langt og havde udvist mangel på god presseskik. Kritiske stemmer efterspørger dog stadig selvransagelse og konsekvenser af de mange sager, hvor den kritiske journalistik blev til deciderede personlige udhængninger. Det skorter dog ikke på debatlitteratur på området, og et hav af bøger er blevet udgivet i kølvandet på det svenske \#metoo-efterår. Matilda Gustafssons Klubben, hvori hun i detaljer beskriver arbejdet med at afsløre kulturprofilen Jean-Claude Arnault, er blevet løftet frem som et eksempel på den kvalitetsjournalistik og det ambitiøse graverarbejde, som også fandt sted, men som dog lige nu ikke virker til at blive \#metoo-journalistens eftermæle. To af de centrale hovedpersoner i den svenske debat, Aftonbladets Frederik Virtanen og medieprofilen Cissi Wallin, som anklagede ham for voldtægt på sin Instagram i oktober 2017, udgav også hver deres bog om forløbet. Virtanens Utan Nåd, hvori han skarpt kritiserer de journalistiske udhængninger udkom på et norsk forlag, efter at bogen var blevet afvist af flere forlag i Sverige. Wallins forlag hoppede af i 11. time, og hun endte med selv at udgive bogen Allt som var mitt, og kort tid efter blev hun sigtet og dømt for grov ærekrænkelse for at komme med voldtægts- 
anklager mod Virtanen på sociale medier. I august 2020 udkom så Åsa Linderborgs dagbogsfortælling Året med 13 måneder, hvori hun gør op med sig selv og de svenske journalistkår i en dybt personlig og stærkt kritisk udlægning af den svenske debat i 2017-2018, ikke bare \#metoo-debatten, men også skandalen i Det Svenske Akademi, ytringsfrihed og feminisme.

I Norge medførte \#metoo ligeledes en reel forandring, ikke mindst fordi bevægelsen har løftet enkeltsagerne op til et strukturelt niveau og især har sat arbejdsgivernes ansvar i fokus. Det politiske magtcentrum blev hurtigt en hovedarena for \#metoo i Norge. Som Anja Sletteland og Kristin Skare Orgeret (2020) har vist, dominerede den såkaldte Giske-saken og konflikten om Arbeiderpartiets daværende formand debatten totalt og vanskeliggjorde i en periode andre \#metoo-diskussioner. I efteråret 2020 startede et oprydningsarbejde i det norske politi, efter en undersøgelse havde dokumenteret en udbredt sexistisk kultur, og så sent som i november 2020 skyllede \#metoo ind over forlagsbranchen i Norge. De stadig nye 'bølger' og efterfølgende diskussioner om, hvorvidt \#metoo 'er gået for langt', viser tydeligt, at bevægelsen på ingen måde er i mål og forsat sætter spørgsmålstegn ved de eksisterende strukturer og hierarkier i journalistikken og i samfundet mere generelt.

På mange måder var diskussionerne allerede godt i gang i Finland i 2017, eftersom hashtaget \#lääppijä ("gramser") tilbage i 2016 satte gang i en bred, offentlig debat om seksuelle krænkelser, efter den finske rigspolitichef i en udtalelse påstod, at seksuelle krænkelser ikke sker i Finland. Et af de første opråb, som \#metoo afstedkom i Finland i 2017, var \#dammenbrister, hvor over 6.000 finlandssvenske kvinder fra den svensksproglige minoritet i Finland fortalte om overgreb. Opråbet, hvis navn er en henvisning til den finlandssvenske minoritet i Finland, som ofte beskrives som en andedam, fik stor gennemslagskraft og generede i de første uger over 800 personlige vidnesbyrd. I Finland har journalister lige fra starten været meget forsigtige med at sætte navn på potentielle overgrebsmænd. De finske mediers forsigtighedsprincip er ikke mindst en følge af en ti år gammel sag, hvor Helsingin Sanomat, den største avis i Finland, navngav folketingsmedlemmer, som ifølge en anonym kilde havde gjort sig skyldig i overgreb. Det finske opinionsnævn for massemedier (ONM) dømte 
på daværende tidspunkt, at anonyme kilder ikke er tilstrækkeligt for en offentliggørelse, men at der kræves yderligere dokumentation.

\#metoo har sat journalistikkens normative grænser i bevægelse, og velkendte diskussioner om journalistikkens rolle i samfundet aktualiseres i relation til spørgsmål om den måde, hvorpå sexchikane, seksuelle overgreb, vold mod og voldtægt af kvinder bliver dækket i medierne. Det rejser i sidste ende spørgsmålet om, hvorvidt og ikke mindst hvordan journalistik skal være med til at bidrage til samfundsmæssige holdningsændringer og forandringer af status quo. I alle de nordiske lande har journalister kæmpet, individuelt og som faggruppe, med de udfordringer og problemstillinger, som \#metoo indebærer. I ingen af landene har mediernes håndtering af \#metoo været uproblematisk eller uden konsekvenser, men et sted på midten findes der måske noget, vi kan lære af hinanden. Derfor er det også så vigtigt med forskning, som nuancerer synet på 'de fælles nordiske lande' og peger på både ligheder og forskelle, hvilket har været formålet med dette temanummer.

Temanummer indeholder i alt tre artikler, som hver især belyser, hvordan \#metoo har sat skub i forandringer, men også hvordan mange eksisterende strukturer reartikuleres og genfindes i en ny kontekst. I en af artiklerne foretager Lisa Lindqvist og Hillevi Ganetz en diskursanalyse af repræsentationerne i medierne af tre større sager fra den svenske dækning og viser, at ansvaret for at gøre op med krænkelser rent sprogligt ofte lægges over på kvinderne. Ydermere sætter dækningen spørgsmålstegn ved kvindernes troværdighed, ligesom det også blev gjort, da Sofie Linde stod frem i Danmark. Ydermere viser de to forfattere, hvordan sagen forsøges fremstillet som en juridisk problemstilling, men at reaktionen på dette i kommentarsporerne faktisk indikerer, at \#metoo har formået at linke seksuelle krænkelser til et strukturelt problem, snarere end enkeltstående cases.

Fra Norge formår artiklen af Kristin Skare Orgeret og Heidi RøsokDahl at trække tråde mellem \#metoo og arbejdsmiljøet på medierne og større strukturelle kønsmæssige hierarkiseringer på selvsamme medier. Via interviews med praktikanter, der ofte er de mest udsatte i de typisk meget mandsdominerede redaktionskulturer, nemlig på sportsredaktioner, viser de to forfattere, hvordan \#metoo også føder 
ind en mere generel debat om kulturen på forskellige redaktioner, og at det efter \#metoo i højere grad ses som mediets ansvar at tage hånd om krænkelser og chikane.

I vores egen artikel 'Man skal jo nødigt blev en kvinde med en sag': Rolleforhandlinger på redaktionerne i dækningen af \#metoo i Danmark og Sverige' kigger vi nærmere på, hvordan journalister i de to lande oplevede at navigere i forskellige roller, idealer og normative positioner i deres professionelle virke under de første intensive måneder af \#metoo-bevægelsen. Med et interviewstudie, der fokuserer på journalisters personlige oplevelser af at bidrage til \#metoodækningen og \#metoo-debatten, kaster vi lys på, hvordan de ved første øjekast beskedne forskelle mellem de nordiske lande på dette område får store konsekvenser for individers mulighedsrum og oplevelse af den personlige pris forbundet ved at være en del af samfundsdebatten på køn- og ligestillingsområdet.

Artiklerne i dette temanummer sætter fokus på et ofte underprioriteret område i journalistikforskningen generelt, nemlig køn, og vi håber, at vi hermed kan sætte skub i mere forskning på dette område og nye projekter inden for medier, køn og ligestillingsområdet, som rækker langt ud over \#metoo.

God læsning,

Tina Askanius og Jannie Møller Hartley

\title{
TINA ASKANIUS
}

Universitetslektor

Institutionen for kunst, kultur og kommunikation (K3)

Malmø Universitet

Östra Varvsgatan 11A, 21119 Malmø, Sverige

tina.askanius@mau.se

\author{
JANNIE MØLLER HARTLEY \\ Lektor \\ Institut for Kommunikation og Humanistisk Videnskab \\ Roskilde Universitet \\ Kommunikationsvej 1, 4000 Roskilde, Danmark \\ jath@ruc.dk
}

